In researches into the biological effects of ultraviolet radiations, Hill measured and compared the effectiveness of various sources by exposing paramecia to the light from arc lamps and the like in quartz cells cooled by water circulation. By observing the relative times taken by these creatures to stop moving, a measure of biological effectiveness was obtained, before suitable photo-electric cells became available. With Mr. T. A. Webster he introduced a simple approximate chemical measurement of ultraviolet radiation from the sun and sky by which for the first time this quantity was measured in different parts of the world.

Hill was an inspiring teacher, and to work under his direction was an education and a delight. $\mathrm{He}$ practised what he preached and was to be seen in Lpping Forest in the early hours in all weathers. He loved sea bathing, animals, and country life generally. He took an active interest in science to the last, and during the last few years of his life, living in a farmhouse in Kent, was a constant writer to the press on scientific subjects. He married, in 1891, Janet, daughter of Mr. Frederick Alexander, who survives him with four sons and a daughter.

$$
\text { T. C. ANGUS }
$$

\section{Dr. Thomas Wayland Vaughan}

Dr. Thomas Wayland Vaughan was one of the old school of biologists. He built up a world-wide reputation in three distinct fields: as an authority on recent and fossil corals, as a pioneer in the study of certain of the larger fossil Foraminifera, and as a leader of investigations into oceanographical problems.

Vaughan was born on September 20, 1870, at Jonesville, Texas, the son of Dr. Samuel and Annie Hope Vaughan. In 1889 he graduated at Tulane University, Texas, where he read widely, learnt the principles of mechanics and mathematics that he was later to apply in working with sediments and on the problems of dynamical oceanography, and began his interest in stratigraphical palæontology. $\mathrm{He}$ taught physics and chemistry during 1889-92 at Mount Lebanon College, Louisiana, but at the same time acquired by field experience that stimulus to ecological research that was to colour all his later work. In 1892 he went to Harvard, where he took his A.B. in 1893, and his A.M. and Ph.D. degrees in 1894 and 1903, respectively. $\mathrm{He}$ was connected with the U.S. Geological Survey in various ways from 1894 until 1939, when he retired after being geologist in charge of coastal plain investigations during 1907-23, senior geologist during 1924-28, and principal scientist from 1928. Vaughan was also custodian of Madreporaria in the U.S. National Museum during 1903-23, and associated with it in other ways almost until his death. He became professor of oceanography and director of the Scripps Institution at the University of California, La Jolla, in 1924, retiring in 1936.

Although Vaughan wrote a few papers on Mesozoic corals, his main investigations on the group were on Tertiary and Recent faunas. He quickly established his reputation by his important monograph (actually his Ph.D. thesis at Harvard). on "The Eocene and Lower Oligocene Coral Faunas of the United States", published by the U.S. Geological Survey in 1900 . Numerous papers followed on fossil corals, notably his large work, "Fossil Corals from Central America, Cuba and Porto Rico, with an Account of the
American Tertiary, Pleistocene, and Recent Coral Reefs" (U.S. Nat. Mus. Bull., 103 ; 1919). This is important not only for its systematic study of the corals, but also for its stratigraphical correlations and the discussion of coral-reef formation. In connexion with this work Vaughan twice visited London to study West Indian type specimens at the British Museum (Natural History) and the Geological Society.

But Vaughan's interest also embraced modern Madreporaria, and he wrote extensively on them. Monographs and shorter papers covered Floridan, Bahaman and West Indian coral faunas, and those of French Somaliland, the eastern Indian Ocean, Kermadec Islands, and the Pacific Ocean. With such a wide knowledge of corals, Vaughan could scarcely fail to have ideas on their classification. These were crystallized in 1943 in a joint work with Dr. John W. Wells, "Revision of the Suborders, Families, and Genera of the Scleractinia" (Geol. Soc. Amer. Special Paper, 44). This revision is based primarily on the structure of the septa, though other skeletal elements are taken into account, as well as the somewhat meagre knowledge of the soft parts. Imaginative in its conception and comprehensive in its treatment, this challenging work is the most important classification of the group which has been made this century.

Investigation of the American fossil corals inevitably led Vaughan to study the problems of sedimentation and correlation of the Tertiary rocks. So he came to pay attention to the early Tertiary larger Foraminifera of the American continent, particularly the orbitoids, which essentially take the place of the nummulites of the Old World. His pioneer researches in this field made a major contribution to stratigraphical palæontology by demonstrating the importance of the orbitoids in correlation and by revealing their evolutionary trends.

Much of this work was published after Vaughan had gone as director to the Scripps Institution of Oceanography, where his ability as organizer and administrator was given full rein. It is to the vision and energy with which he laid the foundations for its present development that that Institution owes its outstanding position in oceanographical research. He was chairman of several committees on various aspects of oceanography, and during 1932-33 made a world tour devoted to the study of provisions for research in that science. One outcome of this was the invaluable "International Aspects of Oceanography" (1937), which he compiled and edited for the U.S. National Academy of Sciences. He also wrote on the ecology of modern marine organisms with reference to palæogeography, and on the classification and nomenclature of the submarine features of the Gulf of Mexico and the Caribbean Sea.

Vaughan's work was widely recognized. The Universities of British Columbia (1933), California (1936) and Tulane (1944) awarded him doctor's degrees. He had been president of a number of societies including the Geological Society of America (1939), which gave him the Penrose Medal in 1946. The U.S. National Academy of Sciences awarded him the Agassiz Medal in 1935 for research in oceanography and the Mary Clark Thompson Medal in 1945 for geology and palæontology. In London he was elected a foreign correspondent of the Geological Society in 1925 and a foreign fellow in 1929, a foreign member of the Linnean Society in 1928, and a corresponding member of the Zoological Society in 
1933. The Emperor Hirohito of Japan received him in private audience in 1933, and in 1940 the Japanese Government awarded him the Order of the Rising Sun (third class).

Vaughan's was a lively mind, which was not restricted to the scientific field. He had studied music in Europe, was a life-long admirer of Oliver Goldsmith, and had a high regard for ancient Greek philosophy. He was a generous host, and a willing helper to those who appealed to him in their scientific work. The last years of his life were clouded by seriously failing eyesight and ill-health. His wife, whom he married in 1909, died in 1951, and he himself, at the age of eighty-one, died on January 16 as the result of a stroke.

H. Dighton Thomas

\section{Dr. Leonard Dobbin}

A LINK with the past has been broken by the death of Dr. Leonard Dobbin, which occurred at Edinburgh on March 3, for Dr. Dobbin was recognized for many decades as one of our leading investigators in the history of chemistry. Born at Belfast on July 30, 1858, Dr. Dobbin in his ninety-fourth year was still actively interested in his favourite field of researchfrail in body, but with mind alert and unimpaired.

His early studies were at Queen's College, Belfast, and at the Royal College of Science, London; in 1880 he obtained the degree of $\mathrm{Ph} . \mathrm{D}$. at Würzburg and was appointed an assistant in the Department of Chemistry at the University of Edinburgh under Prof. Crum Brown. In 1894 he was promoted to a lectureship, and retired with the rank of reader in 1924.

A number of experimental papers between 1880 and 1893 showed Dobbin's skill as an organic chemist, and his text-book "Salts and their Reactions", written in collaboration first with Dr. Hugh Marshall and later with Dr. J. E. Mackenzie, has been in favour for nearly fifty years. But the historical development of chemistry became his main study, and in 1899 he organized the five non-professorial members of the teaching staff of the chemistry department in the University of Edinburgh into the Alembic Club, an unassuming body which was destined to play a useful part in bringing important chemical communications within the reach of interested readers. The twenty-one "Alembic Club Reprints" now available in booklet form reproduce the classical investigations of the greatest chemists of the past three centuries. Many of these reprints were edited or translated by Dr. Dobbin himself.

His translation of Ladenburg's "Lectures on the History of the Development of Chemistry since the Time of Lavoisier" was published in 1900, and his translation from Swedish and German originals of "The Collected Papers of Carl Wilhelm Scheele" appeared in 1931. These were his two major works; minor contributions elucidating points of dubiety or matters of controversy in chemical history flowed from his pen continually.

Dr. Dobbin was an active member of many scientific societies. He was elected a Fellow of the Royal Society of Edinburgh in 1881, and his seventy-one years of membership probably constituted a record. He served on the Council of the Society during 1904-7 and during 1913-16, was curator from 1934 until 1939, and vice-president during 1939-42. He was also the doyen of the Society of Chemical Industry.

One of the most modest of men, and one of the most lovable.
JAMES KENDALL

\section{NEWS and VIEWS}

Theoretical Physics at King's College, London : Prof. H. C. Longuet-Higgins

THE appointment of Dr. H. C. Longuet-Higgins to the chair of theoretical physics at King's College, University of London, has recently been announced. Prof. Longuet-Higgins, who is not yet thirty years of age, is one of the youngest professors in Britain. The present appointment is particularly interesting as he follows Prof. C. A. Coulson (see Nature, 168, 236 (1951) and 159,632 (1947)), under whom he studied for his D.Phil. at Oxford. Two years after graduating in chemistry at Oxford with first-class honours, he was elected to a fellowship at Balliol. This was followed after two or three more years by a period with Prof. R. S. Mulliken at Chicago. Prof. Longuet-Higgins has been recently in the University of Manchester, where he has been successively lecturer and reader in theoretical chemistry. Prof. Longuet-Higgins's interests are wide. $\mathrm{He}$ has made notable contributions to the study of aromatic and conjugated molecules, both as regards their structure and reactivity. While still an undergraduate, together with Mr. R. P. Bell, he helped to revive and develop a bridge model for the boron hydrides and other electron-deficient molecules. He has recently discussed the thermodynamic properties of liquid mixtures and has applied the methods of group theory to molecular vibrations. Prof. Longuet-Higgins is unmarried; he is a keen mountaineer and an accom- plished musician, both in conducting and in playing. He will be warmly welcomed in London.

Mathematics at Manchester: Prof. K. Mahler, F.R.S.

DR. KURT MAHLER has been awarded the status of professor of mathematical analysis in the University of Manchester, a mark of recognition of his mathematical distinction that will be welcomed by his many friends and pupils. Dr. Mahler began his mathematical studies in Frankfurt under Prof. C. L. Siegel and, except for some early work on functions of a complex variable, has devoted himself entirely to one aspect or another of the theory of numbers. His first main interest was in the theory of transcendental numbers, and particularly in the closeness with which they can be approximated by rationals with a given denominator. This work led him to consider the extension of the theory of transcendental numbers to the $p$-adic number-field, and he established a number of important theorems, culminating in his generalization of the Thue-Siegel theorem, on one hand, and his theory of 'pseudo-valuations' on the other. Soon after joining Prof. L. J. Mordell's staff in Manchester, he turned his attention to the geometry of numbers. Taking as his starting-point Mordell's theory of lattice points in non-convex domains, he has in the past ten years published a series of papers. in which Minkowski's methods are used for studying the lattice-points of 'star-domains' in two and more. 